\title{
Effect of detergent surfactant on some selected electrolytes and metabolites of juvenile Heterobranchus bidorsalis
}

\section{Gabriel Olarinde Mekuleyi ${ }^{1}$ and Babajide Elijah Faleti $^{2}$}

${ }^{1}$ Department of Fisheries. Faculty of Science. Lagos State University. Ojo. Lagos. Nigeria. Email: gabrielmekuleyi@gmail.com.

${ }^{2}$ Department of Fisheries Technology. Lagos State Polytechnics. Ikorodu. Lagos. Nigeria.

\begin{abstract}
The study examined the effect of sub-lethal level of Linear Alkylbenzene Sulphonates (LAS) on some selected electrolyte and metabolic indices of juvenile Heterobranchus bidorsalis. The fish were exposed to varying concentrations of LAS $(0.00 \mathrm{mg} / \mathrm{L}, \quad 0.01 \mathrm{mg} / \mathrm{L}, 0.02 \mathrm{mg} / \mathrm{L}$ and $0.03 \mathrm{mg} / \mathrm{L}$, respectively) in a semi-static tank for 14 days. The chemical test analysis of LAS showed that only total suspended solid $(196.8 \mathrm{mg} / \mathrm{L})$, total alkalinity $(56.1 \mathrm{mg} / \mathrm{L})$ and nitrate $(7.9 \mathrm{mg} / \mathrm{L})$ exceeded Federal Environmental Protection Agency (FEPA) and Standard Organization of Nigeria (SON) permissible limits. Conductivity and dissolved oxygen (DO) of the water parameter differ significantly $(\mathrm{p}<0.05)$ from the control and among dose concentration. Electrolyte values $\left(\mathrm{K}^{+}\right.$and $\left.\mathrm{Ca}^{2+}\right)$ were not significantly $(p>0.05)$ different at all level of LAS concentration. However, there were significant $(p<0.05)$ differences in $\mathrm{Na}^{+}$ concentration. The highest value for $\mathrm{Na}^{+}(16.00 \pm 1.16 \mathrm{Mmol} / \mathrm{L})$ was obtained at $0.02 \mathrm{mg} / \mathrm{L}$, while the least $(5.35 \pm 0.45 \mathrm{Mmol} / \mathrm{L})$ was recorded in the control at $0.00 \mathrm{mg} / \mathrm{L}$. There was significant $(\mathrm{p}<0.05)$ differences in values of urea in the experimental group, except between $0.01 \mathrm{mg} / \mathrm{L}(1.53 \pm 0.05 \mathrm{mg} / \mathrm{dm})$ and $0.02 \mathrm{mg} / \mathrm{L}(1.60 \pm 0.06 \mathrm{mg} / \mathrm{dm}) .0 n$ the contrary, there were significant $(\mathrm{p}<0.05)$ differences in all the values of creatinine recorded in this study. The values increased down the experimental group in a dose dependent pattern. The highest value of creatinine $(54.45 \pm 4.96 \mathrm{mg} / \mathrm{dm})$ was recorded at $0.03 \mathrm{mg} / \mathrm{L}$ dose concentration while the least $(30.47 \pm 7.65$ $\mathrm{mg} / \mathrm{dm})$ was obtained in the control $(0.00 \mathrm{mg} / \mathrm{L})$. The present study concluded that LAS has impact on the metabolites and electrolytes especially creatinine and the $\mathrm{Na}^{+}$. Therefore, LAS could be very toxic at high concentrations and as such, indiscriminate discharge of LAS effluent into aquatic environment should be averted.
\end{abstract}

Keywords: Electrolytes, Surfactant, Heterobranchus bidorsalis, Toxicity, Metabolite.
Received

August 1, 2018

Accepted

August 29, 2018

Released

August 31, 2018

Full Text Article

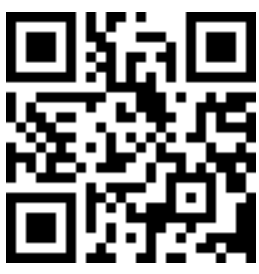

ORCID

(1) 0000-0002-1030-2518

Gabriel Olarinde Mekuleyi

(ㄱ) 0000-0002-1340-5635 Babajide Elijah Faleti 


\section{Introduction}

The health of aquatic ecosystem is often threatened by its exposure to toxic substances and compounds. Recently, researchers in Nigeria have begun to give special attention towards examining the various freshwater pollutants especially detergents. As a result of large scale application of detergents in washing powders, tooth powder, dye fasteners, formulation of shampoos, industrial and household cleansing agents etc, it has become a notorious source of contamination to the aquatic ecosystem (Spirita et al., 2015).

Out of all the known surfactants in Nigeria, Linear Alkylbenzene Sulphonate (LAS) is one of the most popularly used surfactant for both industrial and domestic purposes. This could be accredited to its ability to lower the surface tension of water, as well as loosen stains from fabrics and surfaces (Spirita et al., 2015).

LAS is relatively aerobically degraded and it is very stable in hard water as well as in low acidic and alkaline media (Oyoroko and Ogamba, 2017). Several fish indices such as mortality, electrolytes, metabolites, enzymatic and biochemical parameters, behavioral response, condition factor, organosomatic, haematological profile (Inyang et al., 2016) and Histopathology (Mekuleyi and Fakoya, 2017) have been used to assess the impact of chemical toxicants on aquatic organism.

Naturally, freshwater fish has the ability to balance electrolytes such as calcium, potassium, chloride, sodium, and magnesium in their body fluids (Skelton, 1993).The electrolytes are extracted from the water by the fish through cells situated in the gills and are essential for the uptake of oxygen and release of carbon dioxide. According to Railo and Nkinmaa (1985), blood parameters of diagnostic importance include electrolytes, haemoglobin, and leucocytes differential count and all these would respond to incidental factors such as physical and environmental stress as a result of xenobiotics in water. However, many at times, it is cumbersome to assess the level of toxicity of surfactant on organisms in the aquatic environment due to the complex nature of aquatic ecosystems. So, toxicological methods became an appropriate technique for assessing toxicants on the aquatic population.

The present study therefore aimed to investigate the effect of sublethal level of a commercial detergent effluent (LAS) on some selected electrolyte and metabolic indices of juvenile Heterobranchus bidorsalis.

\section{Materials and methods}

\section{Collection of fish samples}

A total of 80 apparently healthy Heterobranchus bidorsalis with average body weight of $140 \mathrm{~g} \pm 12 \mathrm{~g}$ and total length $(18 \pm 2.6 \mathrm{~cm})$ were bought from a reputable farm in Sango Otta, Ogun State, Nigeria, and later transferred to Emmadav Farm, in Akesan, Lagos State, Nigeria, where the experiment was conducted. At Emmadav Farm, the fish were acclimatized for 7 days in 2 concrete tanks (300 L water for each) as 40 fish/tank during which they were fed twice daily with Aller Aqua feed of 64\% crude protein (Table 1).

After that, they were randomly redistributed into 4 PVC tank supplied with chlorine-free tap water and continuous aeration in a rate of 20 fish/tank. The fish groups in first tank (control) received zero $\mathrm{mg} / \mathrm{L}$ of the LAS diluent, while the fishes in tank 2-4 received $0.01 \mathrm{mg} / \mathrm{L}, 0.02 \mathrm{mg} / \mathrm{L}, 0.03$ $\mathrm{mg} / \mathrm{L}$ of the diluents, respectively, for 14 days. The physicochemical parameters of the water used for fish bioassay was carried out using standard methods of APHA (2005). These parameters included temperature, dissolved oxygen, $\mathrm{pH}$, conductivity and turbidity. Similarly, the chemical component of the test reagent (LAS) was examined following APHA (2005) methods. 
Table 1. Gross composition of aller-aqua feed fed to sample fish.

\begin{tabular}{|l|c|}
\hline Parameter & Value \\
\hline Sizes of feed (mm) & 2 \\
\hline Crude protein (\%) & 64 \\
\hline Crude fat (\%) & 12 \\
\hline Nitrogen free extract (\%) & 4 \\
\hline Fiber (\%) & 1 \\
\hline Ash (\%) & 11 \\
\hline Potassium total & 1.5 \\
\hline Sodium total & 0.9 \\
\hline Calcium total & 2.5 \\
\hline
\end{tabular}

\section{Preparation of diluent and bioassay technique}

Sublethal concentrations of LAS for the assay $(0.01 \mathrm{mg} / \mathrm{L}, 0.02 \mathrm{mg} / \mathrm{L}, 0.03$ $\mathrm{mg} / \mathrm{L}$ ) were prepared by following procedures describe by Inyang (2008). These were prepared by transferring $0.01 \mathrm{~mL}, \quad 0.02 \mathrm{~mL}$ and $0.03 \mathrm{~mL}$, respectively, from the original concentration $(250 \mathrm{~g} / \mathrm{L})$ of the toxicant and making it up with chlorine-free tap water in the test. No diluent was added to the tank used as control. The assay was conducted between 20th November - 3rd December, 2017. Two replications of each treatment concentrations were set up by introducing fishes individually into each tank. The exposed media were renewed every $48 \mathrm{~h}$.

\section{Collection of blood samples}

Blood samples were collected according to the procedure of Tommasso et al. (1980). Fish were caught individually and then placed belly upwards. $3 \mathrm{~cm}$ from the genital opening was wiped dry with tissue paper to avert contamination with mucus. Then, a gauge disposable hypodermic needle was inserted perpendicularly to the vertebral column of the fish and gently aspirated during penetration, and gently pushed down until blood started to enter as the needle punctured a caudal blood vessel to obtain about $1 \mathrm{~cm}^{3}$ of blood. Then the needle was withdrawn and the blood gently transferred into lithium heparin anticoagulant tube and allowed to clot at room temperature for 30-40 min. Thereafter, the sample was taken to the laboratory for further analysis.

\section{Centrifuging of blood sample}

The blood in the anticoagulant tubes were collected and then transferred into clean dry centrifuge tubes and centrifuged at $4000 \mathrm{rpm}$ for 10 min, followed by serum separation.

\section{and metabolites \\ Determination of electrolyte}

The electrolytes such as calcium $\left(\mathrm{Ca}^{2+}\right)$, sodium $\left(\mathrm{Na}^{+}\right)$and potassium $\left(\mathrm{K}^{+}\right)$ are determined according to the method described by Adedeji et al. (2009), while the metabolite are determined by following the method of APHA (2005), and Iyang and Thomas (2016).

\section{Statistical analysis}

The data were subjected to one way analysis of variance (ANOVA). Where differences exist, Duncan multiple range test were used to test for pair wise significant differences $\quad(p<0.05)$ between treatments.

\section{Results}

The chemical parameters of the test reagent (LAS) were compared with some standard values as shown in Table 2. The result showed that aside total suspended solid (196.8 mg/L) and total alkalinity (56.1 $\mathrm{mg} / \mathrm{L})$ which exceeded maximum limit recommended 
by FEPA (2007), and nitrate $(7.9 \mathrm{mg} / \mathrm{L})$ that was higher than values recommended by FEPA (2007) and SON (2007), respectively, all other parameters are below the maximum permissible limits recommended in water by WHO (2006), SON (2007), and FEPA (2007), respectively.

Table 2. Comparison of chemical analysis of LAS with SON, FEPA and WHO limits.

\begin{tabular}{|l|c|c|c|c|}
\hline Parameter (mg/L) & $\begin{array}{c}\text { Detergent } \\
\text { surfactact } \\
\text { (LAS) used for } \\
\text { this study }\end{array}$ & $\begin{array}{c}\text { SON (2007) - } \\
\text { Maximum } \\
\text { Permissible } \\
\text { Limit }\end{array}$ & $\begin{array}{c}\text { WHO (2006) } \\
\text { - Maximum } \\
\text { Permissible } \\
\text { Limit }\end{array}$ & $\begin{array}{c}\text { FEPA (2007) - } \\
\text { Maximum } \\
\text { Permissible } \\
\text { Limit }\end{array}$ \\
\hline Total hardness & 50.6 & 100 & 100 & 100 \\
\hline Total suspended solid & 196.8 & 500 & 500 & 30 \\
\hline pH & 8.5 & $6-9$ & $7-9.2$ & $6-8.5$ \\
\hline Dissolved oxygen & 3.02 & $>4.0$ & $>4.0$ & $>3.0$ \\
\hline Total alkalinity & 56.1 & 100 & 100 & 45 \\
\hline $\begin{array}{l}\text { Biochemical oxygen } \\
\text { demand }\end{array}$ & 57.9 & 50 & 6 & 50 \\
\hline Manganese & 0.36 & 0.5 & 0.5 & 0.5 \\
\hline Nitrate & 7.9 & $<1$ & $\mathrm{~N} / \mathrm{A}$ & $<1$ \\
\hline Cadmium & 0.05 & 0.05 & 0.003 & $<1$ \\
\hline Zinc & 1.32 & 3 & 5 & $<1$ \\
\hline Copper & 0.21 & 0.4 & 0.04 & $<1$ \\
\hline
\end{tabular}

Water quality parameters significantly differs $(p<0.05)$ from the control and among dose concentration only for conductivity and dissolved oxygen (Table 3 ). While the dissolved oxygen decreases in values as the concentration of doses increases, there was an increase in values of conductivity as the dose increased. The highest conductivity value $(136.13 \pm 0.06 \mu \mathrm{S} / \mathrm{cm})$ was recorded at $0.03 \mathrm{mg} / \mathrm{L}$ concentration of LAS addition, while the least (98.74 \pm $0.06)$ was obtained at the control level of $0.00 \mathrm{mg} / \mathrm{L}$. In contrast, the highest DO $(8.01 \pm 0.04 \mathrm{mg} / \mathrm{L})$ was obtained in the control level while the least value of DO $(6.38 \pm 0.02 \mathrm{mg} / \mathrm{L})$ was recorded at $0.03 \mathrm{mg} / \mathrm{L}$ concentration of LAS.

Table3. Parameters of water in which concentrations of Alkybenzene Sulphate was added for 14 days.

\begin{tabular}{|l|c|c|c|c|c}
\hline LAS $(\mathbf{m g} / \mathbf{L})$ & $\begin{array}{c}\text { Conductivity } \\
(\boldsymbol{\mu s} / \mathbf{C m})\end{array}$ & $\mathbf{p H}$ & DO $(\mathbf{m g} / \mathbf{L})$ & $\begin{array}{c}\text { Temperature } \\
\left({ }^{\mathbf{0}} \mathbf{C}\right)\end{array}$ & $\begin{array}{c}\text { Turbidity } \\
(\mathbf{N T U})\end{array}$ \\
\hline 0.00 & $98.74 \pm 0.06^{\mathrm{a}}$ & $6.45 \pm 0.02^{\mathrm{a}}$ & $8.01 \pm 0.04^{\mathrm{b}}$ & $25.28 \pm 0.15^{\mathrm{a}}$ & $0.26 \pm 0.04^{\mathrm{a}}$ \\
\hline 0.01 & $110.47 \pm 0.01^{\mathrm{ab}}$ & $6.57 \pm 0.03^{\mathrm{a}}$ & $7.32 \pm 0.01^{\mathrm{a}}$ & $26.25 \pm 0.14^{\mathrm{a}}$ & $0.32 \pm 0.01^{\mathrm{a}}$ \\
\hline 0.02 & $133.28 \pm 0.05^{\mathrm{b}}$ & $6.35 \pm 0.02^{\mathrm{a}}$ & $7.21 \pm 0.02^{\mathrm{a}}$ & $25.48 \pm 0.12^{\mathrm{a}}$ & $0.33 \pm 0.01^{\mathrm{a}}$ \\
\hline 0.03 & $136.13 \pm 0.06^{\mathrm{bc}}$ & $6.30 \pm 0.01^{\mathrm{a}}$ & $6.38 \pm 0.02^{\mathrm{bc}}$ & $25.50 \pm 0.14^{\mathrm{a}}$ & $0.41 \pm 0.02^{\mathrm{a}}$ \\
\hline
\end{tabular}

Mean value with same superscript in the column are not significantly different. 
The electrolytes $\left(\mathrm{Ca}^{2+}, \mathrm{Na}^{+}, \mathrm{K}^{+}\right)$ activities recorded in the blood sample Heterobranchus bidorsalis exposed to sublethal concentration of LAS for 14 days is presented in Table 4. Electrolyte values $\left(\mathrm{K}^{+}\right.$and $\left.\mathrm{Ca}^{2+}\right)$ were not significantly $(\mathrm{p}>0.05)$ different at all level of LAS concentration. However, there were significant $(\mathrm{p}<0.05)$ differences in $\mathrm{Na}^{+}$concentration. The highest value $(16.00 \pm 1.16 \mathrm{Mmol} / \mathrm{L})$ was obtained at $0.02 \mathrm{mg} / \mathrm{L}$, while the least $(5.35 \pm 0.45 \mathrm{Mmol} / \mathrm{L})$ was recorded in the control at $0.00 \mathrm{mg} / \mathrm{L}$. On the other hand, the $\mathrm{Na}+$ value between $0.01 \mathrm{mg} / \mathrm{L}$ and $0.03 \mathrm{mg} / \mathrm{L}$ did not differ ( $\mathrm{p}>0.05$ ). The metabolites (urea and creatinine) activity in the blood sample of Heterobranchus bidorsalis exposed to LAS for 14 days is also shown in Table 4.

Table 4. Metabolite activities and some electrolyte in the blood sample of $H$. bidorsalis.

\begin{tabular}{|l|c|c|c|c|c|}
\hline $\begin{array}{l}\text { Akylbenzene } \\
\text { (mg/L) }\end{array}$ & $\begin{array}{c}\text { Urea } \\
(\mathbf{m g} / \mathbf{d m})\end{array}$ & $\begin{array}{c}\text { Creatinine } \\
(\mathbf{m g} / \mathbf{d m})\end{array}$ & $\begin{array}{c}\mathbf{N a}+ \\
(\mathbf{M m o l} / \mathbf{L})\end{array}$ & $\begin{array}{c}\mathbf{K}^{+} \\
(\mathbf{M m o l} / \mathbf{L})\end{array}$ & $\begin{array}{c}\mathbf{C a}^{2+} \\
(\mathbf{M m o l} / \mathbf{L})\end{array}$ \\
\hline 0.00 & $4.70 \pm 0.06^{\mathrm{a}}$ & $30.47 \pm 7.65^{\mathrm{a}}$ & $5.35 \pm 0.45^{\mathrm{a}}$ & $3.15 \pm 0.96^{\mathrm{a}}$ & $0.32 \pm 0.06^{\mathrm{a}}$ \\
\hline 0.01 & $1.53 \pm 0.05^{\mathrm{b}}$ & $36.67 \pm 8.54^{\mathrm{ab}}$ & $12.85 \pm 1.05^{\mathrm{ab}}$ & $4.05 \pm 0.67^{\mathrm{a}}$ & $0.10 \pm 0.08^{\mathrm{a}}$ \\
\hline 0.02 & $1.60 \pm 0.26^{\mathrm{b}}$ & $48.59 \pm 10.82^{\mathrm{b}}$ & $16.00 \pm 1.16^{\mathrm{b}}$ & $3.50 \pm 0.47^{\mathrm{a}}$ & $0.16 \pm 0.05^{\mathrm{a}}$ \\
\hline 0.03 & $3.62 \pm 0.18^{\mathrm{c}}$ & $54.45 \pm 4.96^{\mathrm{bc}}$ & $13.00 \pm 0.87^{\mathrm{ab}}$ & $2.64 \pm 0.46^{\mathrm{a}}$ & $0.31 \pm 0.07^{\mathrm{a}}$ \\
\hline
\end{tabular}

Mean value with same superscript in the column are not significantly different.

There was significant $(\mathrm{p}<0.05)$ differences in values of urea in the experimental group, except between 0.01 $\mathrm{mg} / \mathrm{L}(1.53 \pm 0.05 \mathrm{mg} / \mathrm{dm})$ and 0.02 $\mathrm{mg} / \mathrm{L}(1.60 \pm 0.06 \mathrm{mg} / \mathrm{dm})$ which did not differ significantly $(p>0.05)$. The fluctuation in urea values in this study was not dose dependent. The least urea value was recorded at $0.01 \mathrm{mg} / \mathrm{L}(1.53 \pm$ $0.05 \mathrm{mg} / \mathrm{dm}$ ) while the highest value $(4.70 \pm 0.06 \mathrm{mg} / \mathrm{dm})$ was obtained at the control level of $0.00 \mathrm{mg} / \mathrm{L}$. On the contrary, there were significant $(p<0.05)$ differences in all the values of creatinine recorded in this study. The values increased down the experimental group in a dose dependent pattern. The highest value of creatinine $(54.45 \pm 4.96$ $\mathrm{mg} / \mathrm{dm}$ ) was recorded at $0.03 \mathrm{mg} / \mathrm{L}$ dose concentration while the least (30.47 \pm $7.65 \mathrm{mg} / \mathrm{dm}$ ) was obtained in the control $(0.00 \mathrm{mg} / \mathrm{L})$.

\section{Discussion}

All the physico-chemical parameters recorded in this study were below the maximum permissive limits recommended by WHO (2006). The result affirmed the biodegradable nature of linear alkylbezene suphonate in an aerobic environment. This also indicated that the chemical reagent used in this study is less harmful at low concentration. A similar finding has been reported on toxicological effect of lindane on fish (Amabye and Semere, 2016). Most of the water parameters which did not differ significantly in this study connote with the report of Onusiruika and Ufodike (1994) when they exposed Clarias gariepinus to Akee apple and apple sausage plant extracts where they reported no significant difference in water quality parameters 
analyzed. However, the fluctuation in values of DO and conductivity both in a dose dependent manner in this study could be attributed to the effect of LAS on the water parameters.

The electrolyte values $\left(\mathrm{K}^{+}\right.$and $\mathrm{Ca}^{2+}$ ) that were not significantly different at all level of LAS concentration in this study could be due to sublethal inclusion of the reagent. This present observation differs from the finding of Adedeji et al. (2009) which reported a significantly higher concentration of plasma potassium in fish exposed to diazinon. Also, the present result was not in parallel to that of Ogamba et al. (2013) which reported a significant increase in the values of $\mathrm{K}^{+}$after toxicant was exposed to Clarias gariepinus. However, a slight fluctuation in $\mathrm{K}^{+}$and $\mathrm{Ca}^{2+}$ could perturb ionic and osmotic regulation in fishes as well as general physiology in the fish. Similar finding has been reported on acute toxicity of cassava mill effluent to the African catfish fingerlings (Oti, 2002). The significant variation in $\mathrm{Na}^{+}$concentration recorded in this study could alter fluid distribution, intra and extracellular acidobasic equilibrium and osmotic pressure of the body fluids (Inyang et al., 2017).

The significant differences in values of urea and creatinine recorded in this study could indicate that the metabolic process of the fish might have been altered as a result of stress induced by the toxicant. Urea and creatinine have been used as important indices to evaluate effects of chemicals on the kidney using both in vivo and in vitro methods (Davis and Bernet, 1994). The presence of metabolites in the blood at high or low concentration is also a very important clinical correlation (Cheesborough, 1992). Chindah et al. (2004) and Solomon and Okomoda (2012) reported that biochemical metabolites of fishes are affected by different environmental factors as well as pesticides.

\section{Conclusion}

The present study concluded that LAS has impact on the metabolites especially creatinine and the $\mathrm{Na}^{+}$. Therefore, LAS could be very toxic at high concentrations and as such, indiscriminate discharge of LAS effluent into aquatic environment should be averted.

\section{Conflict of interest}

We declared that that there is no conflict of interest.

\section{References}

Adedeji, O. B.; Adeyemo, O. K.; Agbede, S. A. Effects of diazinon on blood parameters in the African Catfish (Clarias gariepinus). African Journal of Biotechnology, v. 8, p. 3940-3946, 2009.

Amabye, T. G.; Semere, T. Bioassay of Lindane (Gamalin 20) to Heterobranchus bidorsalis juveniles. Journal of Analytical and Bioanalytical Techniques, v. 7, p. 332-336, 2016.

APHA - American Public Health Association. Standard methods for the examination of water and wastewater. 21. ed. Washington, DC: APHA, 2005.

Cheesborough, M. Medical laboratory manual for tropical countries. Cambridge: Bultlework. Cambridge Press, 1992.

Chindah, A. C.; Sikori, F. D.; Vincent-Akpu, J. Changes in haematological characteristics of a bony fish, Tilapia guineensis (Bleeker, 1862), exposed to common pesticides in the Niger Delta Wetland, Nigeria. Ghana Journal of Agricultural Science, v. 37, no. 1, p. 59-67, 2004.

Davis, M. E.; Bernat, W. O. Renal methods for toxicology, in Hayes. Harvard Publication, 1994.

FEPA - Federal Environmental Protection Agency. Guidelines and standards for environmental pollution control in Nigeria. 2007.

Inyang, I. R.; Okon, N. C.; Izah, S. C. Effect of glyphosate on some enzymes and electrolytes in Heterobranchus bidosalis (a 
common African catfish). Biotechnological Research, v. 2, no. 4, p. 161-165, 2016.

Inyang, I. R.; Ollor, A. O.; Izah, S. C. Effect of diazinon on organosomatic indices and behavioural responses of Clarias gariepinus (a common Niger Delta Wetland Fish). Greener Journal of Biological Science, v. 7, no. 2, p. 15-19, 2017.

Inyang, I. R.; Thomas, S.; Izah, S. C. Activities of electrolytes in kidney and liver of Clarias gariepinus exposed to fluazifop-p-butyl. Journal of Biotechnological Research, v. 2, no. 9, p. 68-72, 2016.

Inyang, I. R. Haematological and biochemical responses of Clarias gariepinus to diazinon. Port Harcourt: Rivers State University of Science and Technology, 2008. (PhD. Thesis).

Mekuleyi, G. 0.; Fakoya, K. A. Comparative Histopathology of gladiator swimming crab (Callinectes pallidus) from two coastal areas in Lagos, Southwest, Nigeria. Journal of Applied Sciences and Environmental Management, v. 21, no. 3, p. 587-591, 2017.

Ogamba, E. N.; Inyang, I. R.; Okechukwu, O. C. Effect of Kartoderm 315ec (Dimethoate + Lambda cyhalothrin on electrolytes of Clarias gariepinus. IOSR Journal of Environmental Science, Toxicology and Food Technology, v. 5, no. 2, p. 1-4, 2013.

Onusiruika, B. C.; Ufodike, F. B. Acute toxicity of water extracts of Akee Apple and Sausage plant on African Catfish, Clarias gariepinus. Journal of Aquatic Science, v.21, no. 1, p. 581-586, 1994.

Oti, E. E. Acute toxicity of cassava mill effluent to the African catfish fingerlings. Journal of Aquatic Sciences, v. 20, no. 2, p. 134-137, 2002.
Oyoroko, E.; Ogamba, E. N. Effects of detergent containing linear alkyl benzene sulphonate on behavioural response of Heterobranchus bidorsalis, Clarias gariepinus and Heteroclarias. Journal of Biotechnological Research, v. 3, no. 3, p. 59-64, 2017.

Railo, E.; Nkinmaa, M. Effect of sampling blood parameters in rainbow trout. Toxicology Letters, v. 3 , no. 1 , p. 25-32, 1985.

Skelton, P. A complete guide to the freshwater fishes of Southern Africa. Halfway House: Southern Book Publishers, 1993.

Solomon, S. G.; Okomoda, V. T. Effect of photoperiod on the haematological parameters of Clarias gariepinus fingerlings reared in water re-circulating system. Journal of Stress physiology and Biochemistry, v. 8, no. 3, p. 247-253, 2012.

SON - Standard Organization of Nigeria. Standards for drinking water quality. Abuja, Nigeria: SON, 2007.

Spirita, S. V.; Kanagapan, M.; Sam, M. D. S.; Avila, V. R. Studies on the toxicity of alkylbenzene sulphonate to zebra fish, Danio rerio Hamilton. Journal of Entomology and Zoology Studies, v. 3, no. 1, p. 204-207, 2015.

Tommasso, J. R.; Davis, K. B.; Parker, N. C. Plasma corticosteroid and electrolyte dynamics of hybrid striped bass (white bass $\times$ striped bass) during netting and hauling. Proceeding of World Mariculture Society, v. 1, p. 303-310, 1980.

WHO - World Health Organization. Guidelines for drinking water quality. Geneva, Netherlands: WHO, 2006. 